\title{
Prognostic usefulness of ACTH in the postoperative period of Cushing's disease
}

\author{
Pablo Abellán-Galiana ${ }^{1,2}$, Carmen Fajardo-Montañana³ ${ }^{3}$ Pedro Riesgo-Suárez ${ }^{4}$, Marcelino Pérez-Bermejo5 \\ Celia Ríos-Pérez ${ }^{6}$ and José Gómez-Vela ${ }^{3}$
}

\author{
${ }^{1}$ Department of Endocrinology, Hospital General Universitari de Castelló, Castellón, Spain \\ 2Department of Medicine, Universidad Cardenal Herrera-CEU, CEU Universities, Castellón, Spain \\ ${ }^{3}$ Department of Endocrinology, Hospital Universitario de la Ribera, Alzira, Spain \\ ${ }^{4}$ Department of Neurosurgery, Hospital Universitario de la Ribera, Alzira, Spain \\ ${ }^{5}$ Department of Nursing, Universidad Católica de Valencia, Valencia, Spain \\ ${ }^{6}$ Centro de Salud Tavernes de la Valldigna, Hospital Comarcal Francesc de Borja, Gandía, Spain
}

Correspondence should be addressed to C Fajardo-Montañana: fajardo_carmon@gva.es

\begin{abstract}
Objectives: To analyze the usefulness of plasma ACTH in predicting CD remission after surgery and to evaluate the prognostic usefulness of ACTH measurement after the cortisol and ACTH nadir (48 h prior to discharge).

Design: A prospective study was made of 65 patients with CD operated upon between 2005 and 2016.

Methods: Postsurgery plasma ACTH and cortisol were measured every $6 \mathrm{~h}$, in the absence of corticosteroid coverage. Hydrocortisone was started in the presence of adrenal insufficiency or cortisol $<55.2 \mathrm{nmol} / \mathrm{L}$. Plasma ACTH was again determined before discharge. Main outcome measure: Usefulness of plasma ACTH in predicting CD remission.

Results: Remission at 3 months of CD was achieved in 56 of 65 cases, with late recurrence in 18 of 58 cases. Following resection, the ACTH nadir was significantly lower referred to late remission (2.8 vs $6.5 \mathrm{pmol} / \mathrm{L} ; P=0.031$ ) and higher for recurrence (2.1 vs $4.8 \mathrm{pmol} / \mathrm{L}$; $P<0.001$ ), and identical results were obtained for the ACTH values before discharge. In the analysis of the ROC curves, nadir and before discharge ACTH values $<1.9 \mathrm{pmol} / \mathrm{L}$ and $<2.6 \mathrm{pmol} / \mathrm{L}$ were respectively indicative of early remission (AUC 0.827; $P<0.001$ ); $<6.2 \mathrm{pmol} / \mathrm{L}$ of remission at 3 months (AUC $0.847 ; P=0.001$ ) and $>3.2 \mathrm{pmol} / \mathrm{L}$ of recurrence (AUC 0.810; $P<0.001$ ) in both ACTH values. A time to ACTH nadir $<46 \mathrm{~h}$ was indicative of early remission (AUC $0.751 ; P=0.001$ ), while a time $>39 \mathrm{~h}$ was indicative of recurrence (AUC 0.773; $P=0.001$ ).

Conclusions: We propose an ACTH value $<3.3 \mathrm{pmol} / \mathrm{L}$ as a good long-term prognostic marker in the postoperative period of CD. Reaching the ACTH nadir in less time is associated to a lesser recurrence rate.
\end{abstract}

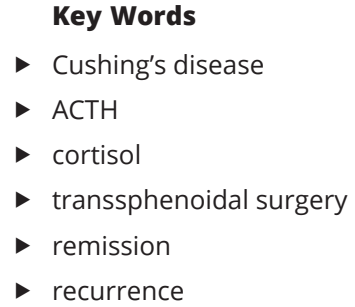

Endocrine Connections (2019) 8, 1262-1272

\section{Introduction}

Transsphenoidal surgery is the treatment of choice in Cushing's disease (CD). Following removal of the pituitary adenoma, the remission rate varies between 25 and 100\% (mean $77.8 \%$, median $78.7 \%$ ), and the recurrence rate ranges from 0 to $65.6 \%$ (mean $13.2 \%$, median $10.6 \%$ ) $(1,2,3,4,5,6)$.
One of the most controversial aspects in the management of CD is the definition of remission criteria (7) and predictive factors.

Different CD remission predictors have been described in the literature, depending on the characteristics of the adenoma (aggressivity and spread, histology, size,

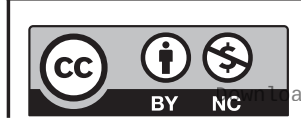

This work is licensed under a Creative Commons Attribution-NonCommercial 4.0 International License. ded from Bioscientifica.com at 04/26/2023 10:31:20AM 
magnetic resonance imaging (MRI) identification of the adenoma, etc.), surgery and the experience of the neurosurgeon and biochemical criteria (8). In this respect, cortisol concentration in the immediate postoperative period has been the most widely used long-term prognostic indicator in most of the published series $(1,4,6,7,8,9$, $10,11,12,13)$.

The guidelines on the management of Cushing's syndrome published in 2015 (14) define CD remission as morning cortisol $<5 \mu \mathrm{g} / \mathrm{dL}(<138 \mathrm{nmol} / \mathrm{L})$ or urinary free cortisol (UFC) $<10-20 \mu \mathrm{g} / 24 \mathrm{~h}(<28-56 \mathrm{nmol} / 24 \mathrm{~h})$ in the 7 days after the operation. However, there is no consensus regarding the cortisol cut-off point after surgery $\quad(<5 \mu \mathrm{g} / \mathrm{dL} \quad(137.9 \mathrm{nmol} / \mathrm{L}), \quad<2 \mu \mathrm{g} / \mathrm{dL}$ $(55.2 \mathrm{nmol} / \mathrm{L}), \quad<1.8 \mu \mathrm{g} / \mathrm{dL} \quad(49.7 \mathrm{nmol} / \mathrm{L}), \quad<1.3 \mu \mathrm{g} / \mathrm{dL}$ $(35.9 \mathrm{nmol} / \mathrm{L})$ or even $<1 \mu \mathrm{g} / \mathrm{dL}(27.6 \mathrm{nmol} / \mathrm{L}))$ or the best time for determining cortisol: $24-48 \mathrm{~h}, 7-14$ days or even months after surgery $(6,7,8,10,11,14,15,16$, $17,18,19,20,21,22,23,24,25,26)$.

Other functional tests have been described in the literature as predictors of recurrence, but they do not improve the results of postoperative basal cortisol, among which are: corticotropin-releasing hormone test (27), metyrapone test (28), desmopressin test $(29,30)$ and dexamethasone suppression test after desmopressin (31). For the interpretation of these last two tests, it is necessary to take into account if glucocorticoids are used in the perioperative period.

Few series have analyzed the usefulness of plasma ACTH after surgery as a prognostic indicator in CD, and the number of patients studied has moreover been very limited $(6,15,25,32,33,34,35,36,37,38,39,40)$. In patients with $\mathrm{CD}$, it would seem reasonable to assume that the plasma ACTH values would decrease markedly in the first $12-24 \mathrm{~h}$ after complete removal of the pituitary adenoma, since the half-life of ACTH is about $10 \mathrm{~min}$.

An ACTH cut-off point of $<34 \mathrm{pg} / \mathrm{mL}(7.5 \mathrm{pmol} / \mathrm{L})$ has been described for identifying patients in remission, with a sensitivity (S) of $80 \%$ and a specificity (Sp) of $97.5 \%$ (17), while other authors define a cut-off point of $<10-20 \mathrm{pg} / \mathrm{mL}(2.2-4.4 \mathrm{pmol} / \mathrm{L})$ as an indicator of adenoma resection $(25,38,40)$. When interpreting the ACTH values, adequate sample processing must be considered, together with the fact that surgical stress (41) and/or manipulation could induce a transient peak.

\section{Study objectives}

The primary objective of this study was to analyze the usefulness of plasma ACTH in predicting $\mathrm{CD}$ remission in the immediate postoperative period $(<72 \mathrm{~h})$ and longterm remission.

The following secondary objectives were defined:

1. Establish early and late disease remission criteria according to plasma ACTH response in the immediate postoperative period and over the subsequent clinical course.

2. To evaluate the prognostic usefulness of ACTH measurement after the cortisol and ACTH nadir, and within the $48 \mathrm{~h}$ prior to discharge (expressed as the last ACTH measurement available in the postoperative period), and its possible correlation to $\mathrm{CD}$ remission and recurrence risk.

\section{Materials and methods}

A prospective study was carried out involving 65 cases of CD (58 patients, with 7 reoperated cases) consecutively referred from 18 centers for surgical treatment between December 2005 and March 2016. The study protocol was authorized by the Ethics Committee of Hospital Universitario de la Ribera (Alzira, Spain), and written informed consent was obtained from all the patients.

Prior to the indication of surgery, bilateral inferior petrosal sinus sampling (BIPSS), with CRH stimulation and concomitant prolactin measurement, were performed on a regular basis in microadenomas measuring $<6 \mathrm{~mm}$ in size or non-visible lesions at MRI, in order to confirm a pituitary origin.

- Perioperative management protocol:

- The specific treatment for hypercortisolism (ketoconazole and/or cabergoline) was suspended before surgery (at least 1 week), avoiding the use of corticosteroids in the surgical phase. Imaging studies using neuronavigation protocols were made, together with a basal pituitary analysis upon patient admission for surgery.

- A trans-naso-septal transsphenoidal approach was used, and all operations were performed by the same expert neurosurgeon. Although the guidelines do not establish a specific recommendation on the performance of hemi-hypophysectomy in those cases in which the adenoma is not identified during surgery, it seems a reasonable option to perform it based on BIPSS findings since prediction accuracy is high and remission rates are significant (42).

- After surgery the patients were moved to intensive care, where plasma cortisol and ACTH 
were determined every $6 \mathrm{~h}$. ACTH sampling and assay were standardized to minimize errors in the measurements. Hydrocortisone was only administered when adrenal insufficiency was confirmed, with suggestive clinical manifestations (mainly arterial hypotension) and/or a cortisol nadir of $<2 \mu \mathrm{g} / \mathrm{dL}(55.2 \mathrm{nmol} / \mathrm{L})$ in asymptomatic patients.

- The patients were moved to the hospital ward once this nadir was reached, or once they were found to be clinically stable without having reached the nadir in the first $72 \mathrm{~h}$. The serial cortisol and ACTH measurements were continued in this latter case. Plasma ACTH was again determined before hospital discharge at 8:00 h, and in case of secondary adrenal insufficiency prior to the dose of hydrocortisone.

- Laboratory methods:

- Cortisol measurement was made using a competitive electrochemoluminescence immunoassay (Elecsys E-170, ROCHE) from 2005 to 2011, and since 2012 using direct chemiluminescence technology (ADVIA Centaur ${ }^{\circledR}$ SIEMENS). Results were interchangeable and showed good agreement (43). The plasma cortisol reference values at 7:00-9:00 $\mathrm{h}$ were $4-24 \mu \mathrm{g} / \mathrm{dL}$ $(110.4-662.2 \mathrm{nmol} / \mathrm{L})$, the minimum detection value being $0.5 \mu \mathrm{g} / \mathrm{dL}(13.8 \mathrm{nmol} / \mathrm{L})$.

- The ACTH values were obtained by electrochemoluminescence immunoassay (Elecsys E-170, ROCHE) from 2005 to 2011, and since 2012 using a sequential immunometric assay with two chemiluminescent binding sites in solid phase (IMMULITE 2000 ACTH®, SIEMENS). Both assays have been compared, showing excellent correlation $(R=0.99)$ (44). The reference values were respectively: $1.00-2000 \mathrm{pg} / \mathrm{mL} \quad(0.220-440 \mathrm{pmol} / \mathrm{L}) \quad$ and $15-65 \mathrm{pg} / \mathrm{mL} \quad(3.3-143 \mathrm{pmol} / \mathrm{L})$, the minimum detection values being $1 \mathrm{pg} / \mathrm{mL}(0.220 \mathrm{pmol} / \mathrm{L})$ and $5 \mathrm{pg} / \mathrm{mL}(1.1 \mathrm{pmol} / \mathrm{L})$, respectively.

- Urinary free cortisol (UFC) was determined in 24-h urine by chemiluminescence (Architect i2000, ABBOTT). The reference values were $20-90 \mu \mathrm{g} / 24 \mathrm{~h}$ $(55.2-248.4 \mathrm{nmol} / 24 \mathrm{~h})$, and the values were also expressed as the number of times above the upper limit of normal (ULN).

- Remission and recurrence criteria:

- The criteria for early $\mathrm{CD}$ remission after transsphenoidal surgery were a cortisol nadir of $<2 \mu \mathrm{g} / \mathrm{dL}(55.2 \mathrm{nmol} / \mathrm{L})$, together with the need for replacement therapy with corticosteroids due to the secondary adrenal insufficiency.

- Remission at 3 months was defined as normality of the hypothalamic-pituitary-adrenal axis 3 months after surgery (cortisol suppression following dexamethasone, absence of UFC elevation and normal nocturnal salivary cortisol levels) or the persistence of secondary adrenal insufficiency treated with corticosteroids.

- Recurrence was defined by confirmed abnormal laboratory test findings (at least two tests were considered to define recurrence being one of them urinary cortisol (and at least two samples)), clinical stigmata and medication dependence after a late remission period.

- Data collection and analysis: The data were coded and entered in an MS Excel 2016 spreadsheet (Microsoft Office 365) for subsequent analysis using the IBM SPSS version 23.0 statistical package. Descriptive, bivariate and multivariate analyses (artificial neural networks (ANNs)) were performed, with the definition of prognostic cut-off points for the main variables based on analysis of the area under the ROC curves (AUC). The results are reported as the mean ( \pm standard deviation (s.D.)). Statistical significance was considered for $P<0.05$ in two-tailed contrasts.

Variables found to be statistically significant in the bivariate analysis were selected as candidates for input into the final ANN model. Sensitivity analysis (importance analysis) was performed to determine the optimum variables for construction of the final ANN model. An exploratory three-layer multiplayer perceptron (MLP) ANN model with a back propagation algorithm was constructed for sensitivity analysis. The data were randomly divided into a training sample (80\%) and a test sample (20\%). Sigmoid transfer functions were used in the hidden and output layers. Gradient descent was used to estimate the synaptic weights. The initial learning rate was 0.4 , and the momentum was 0.9. According to the results of the univariate and sensitivity analyses, a final three-layer feed-forward ANN model with a back propagation algorithm was constructed for all patients. The ANN model was trained with a maximum of 500 iterations and 10 tours.

The analysis for this study was made on August 1, 2016 as cut-off date, after a mean follow-up of 64.18 (32.53) months.
This work is licensed under a Creative Commons Attribution-NonCommercial 4.0 International License. ded from Bioscientifica.com at 04/26/2023 10:31:20AM via free access 


\section{Results}

The baseline characteristics of the 65 operated cases (corresponding to 58 patients) are shown in Table 1. In addition to the seven reoperations in our series due to CD persistence or recurrence, a first operation had been performed in four cases in another center.

The pituitary adenoma was identified by MRI in 59/65: 43 were microadenomas and 16 macroadenomas, with a mean size of $8.3 \mathrm{~mm}$ (s.D. 6.3). The adenoma could be located intraoperatively in four of the six cases lacking an MRI image (Table 1). Resection proved macroscopically complete in $56 / 65$ cases. In two cases hemi-hypophysectomy guided by BIPSS was performed. Remaining tissue on the MRI scan after surgery was absent in 60/65 and non-resectable cavernous sinus tissue was present in $3 / 65$.

There were no postoperative complications in 40 of the 65 cases. The most frequent problems were transient diabetes insipidus (14 cases), which proved irreversible in only one case.

Table 2 shows the mean plasma cortisol and ACTH nadir concentrations after surgery, the time taken to reach them and the plasma ACTH level prior to hospital discharge. A correlation was observed between the cortisol nadir and the ACTH nadir $(R=0.656$, Spearman test; $P=0.001$ ).

The impact of transsphenoidal resection upon the clinical course of $\mathrm{CD}$ was as follows: persistence in 7/65 cases; early remission in 38/65 (40 cases reached cortisol nadir $<2 \mu \mathrm{g} / \mathrm{dL}(55.2 \mathrm{nmol} / \mathrm{L}))$ and 53 cases were prescribed glucocorticoids at discharge, with a mean glucocorticoid

Table 1 Baseline characteristics.

\begin{tabular}{lc}
\hline Qualitative variables & No of patients $(n=65)$ \\
\cline { 1 - 1 } $\begin{array}{l}\text { Gender } \\
\quad \text { Female }\end{array}$ & 53 \\
Previous surgery in another center & \\
$\quad$ No & 61 \\
Yes & 4 \\
MRI identification of the adenoma & 6 \\
No & 43 \\
Microadenoma & 16 \\
Macroadenoma & Mean (s.D.) \\
\hline Quantitative variables & $44(13)$ \\
\hline Age (years) & $8.3(6)$ \\
Adenoma size on MRI scan (mm) & $3.5(2.8)$ \\
Presurgery UFC/ULN & $687.4(226.2)$ \\
Presurgery cortisol (nmol/L) & $16.3(12.2)$ \\
Presurgery ACTH (pmol/L) &
\end{tabular}

MRI, magnetic resonance imaging; S.D., standard deviation; UFC, urinary free cortisol; ULN, upper limit of normal (reference). treatment time of 16.4 (19.7) (1-117) months; late remission in $56 / 65$ cases, with a mean remission follow-up time of 45.5 (34.8) (1-72) months; and recurrence in 18 of the 58 cases, with a mean time to recurrence of 22.9 (21.6) (1-72) months. There were four deaths in the course of follow-up (three due to ischemic heart disease and one due to pneumonia).

Statistically significant differences were observed in the diagnostic categories established by MRI prior to surgery with regard to the cortisol and ACTH nadir values, time to cortisol and ACTH nadir and the value of the last ACTH measurement (Table 2).

With regard to the impact of transsphenoidal resection upon the clinical course of $\mathrm{CD}$, Table 3 reports the outcomes according to the MRI-based diagnostic category.

No statistically significant differences were found between the mean ACTH nadir and the last ACTH measurement. In both cases, the mean values were significantly lower in microadenomas, as well as for short- and long-term remission. Conversely, the mean values were higher in macroadenomas and in patients with persistence and recurrence of $\mathrm{CD}$ after surgery (Tables 2 and 4).

ANN analysis was performed of late remission and recurrence in order to identify predictors of good longterm prognosis. The ACTH nadir, ACTH at discharge and cortisol nadir values were found to be postsurgical variables of greater relevance in predicting remission at 3 months (AUC 0.988) (Fig. 1). The independent variables of greatest weight in predicting recurrence were ACTH at discharge, time to ACTH nadir and reintervention (AUC 0.932) (Fig. 2).

The area under the receiver-operating characteristic curve (AUC) was used to assess the accuracy of the association between postoperative ACTH nadir levels and non-persistence, early remission, late remission and recurrence. The optimum ACTH nadir predictive of persistence was $>28.05 \mathrm{pg} / \mathrm{mL}(6.2 \mathrm{pmol} / \mathrm{L})$, with a sensitivity (S) of $71.4 \%$, a specificity (Sp) of $91.2 \%$ and an AUC of 0.847 (95\% confidence interval $(95 \%$ CI) $0.666-1.000 ; \quad P=0.003)$. The optimum ACTH nadir predictive of early remission was $<8.75 \mathrm{pg} / \mathrm{mL}(1.9 \mathrm{pmol} / \mathrm{L})$ (S 59.5\%, E 92.6\%, AUC 0.828 (95\% CI 0.730-0.926); $P<0.001)$. The optimum ACTH nadir value predictive of remission at 3 months was $<28.05 \mathrm{pg} / \mathrm{mL}(6.2 \mathrm{pmol} / \mathrm{L})$ (S 92.7\%, Sp 66.7\%, AUC 0.846 (95\% CI 0.696-0.997); $P<0.001)$ and for recurrence $>14.7 \mathrm{pg} / \mathrm{mL}(3.2 \mathrm{pmol} / \mathrm{L})$ (S 77.8\%, Sp 79.5\%, AUC 0.811 (95\% CI 0.687-0.934); $P<0.001)$. We obtained similar cut-off results for ACTH determination before discharge (Fig. 3).

This work is licensed under a Creative Commons Attribution-NonCommercial 4.0 International License. ded from Bioscientifica.com at 04/26/2023 10:31:20AM via free access 
Table 2 Cortisol nadir mean values and times, ACTH nadir mean values and times and ACTH before hospital discharge (last ACTH).

\begin{tabular}{|c|c|c|c|c|}
\hline & \multicolumn{3}{|c|}{ MRI identification of the adenoma } & \multirow[b]{3}{*}{$\mathbf{S S}^{\mathbf{a}}(P)$} \\
\hline & Microadenoma $(n=43)$ & Macroadenoma $(n=16)$ & No imaging data $(n=6)$ & \\
\hline & Mean (S.D.) & Mean (S.D.) & $\begin{array}{c}\text { Mean (S.D.) } \\
\end{array}$ & \\
\hline Cortisol nadir (nmol/L) & $81.1^{\mathrm{b}}(117.0)$ & $254.1^{\mathrm{b}}(305.4)$ & $186.2(342.1)$ & 0.016 \\
\hline Time to cortisol nadir (h) & $46.6^{c}(28.2)$ & $84.3^{c}(38.7)$ & $56.0(29.7)$ & 0.001 \\
\hline ACTH nadir (pmol/L) & $3.1^{\mathrm{b}}(3.6)$ & $9.6^{\mathrm{b}}(13.4)$ & $2.6(2.0)$ & 0.011 \\
\hline Time to ACTH nadir $(\mathrm{h})$ & $46.6^{\mathrm{b}}(33.0)$ & $77.7^{\mathrm{b}}(38.9)$ & $38.0(23.1)$ & 0.006 \\
\hline Last ACTH measurement (pmol/L) & $3.1^{\mathrm{b}}(3.5)$ & $9.6^{b}(13.4)$ & $2.6(2.0)$ & 0.010 \\
\hline Time of last ACTH measurement (h) & $130(52)$ & $162(54)$ & $111(37)$ & 0.061 \\
\hline
\end{tabular}

'Significant differences between macroadenomas and microadenomas (Scheffe test and Bonferroni test; $P<0.01$ ).

The cut-off points of the ACTH nadir affording a specificity of $100 \%$ would be $66.5 \mathrm{pg} / \mathrm{mL}(14.6 \mathrm{pmol} / \mathrm{L})$ for persistence, $6.9 \mathrm{pg} / \mathrm{mL}(1.5 \mathrm{pmol} / \mathrm{L})$ for early remission, $6.9 \mathrm{pg} / \mathrm{mL}(1.5 \mathrm{pmol} / \mathrm{L})$ for remission at 3 months and $36.1 \mathrm{pg} / \mathrm{mL}(7.9 \mathrm{pmol} / \mathrm{L})$ for recurrence, though at the expense of poorer sensitivity values of 57.1, 48.6, 32.7 and $22.2 \%$, respectively.

A time to ACTH nadir of under $46 \mathrm{~h}$ was indicative of early remission (S 75.7\%, Sp 74.1\%, AUC 0.751 (0.619-0.882); $P=0.001)$, while a time over $39 \mathrm{~h}$ was indicative of recurrence (S 69.2\%, Sp 83.3\%, AUC 0.773 (0.629-0.917); $P=0.001)$. In the case of persistence and remission at 3 months, the ROC curves referred to the time to ACTH nadir were not valid, since AUC $<0.600$.

Further AUC analyses were performed to assess the prognostic value of the cortisol nadir and time to reach it. The cortisol nadir predictive of early remission was $<1.95 \mu \mathrm{g} / \mathrm{dL}(53.8 \mathrm{nmol} / \mathrm{L})(\mathrm{S} 100 \%$, Sp 92.6\%, AUC 0.976
(95\% CI 0.938-1.000); $P<0.001$ ). The optimum cortisol nadir value predictive of remission at 3 months was $<2.78 \mu \mathrm{g} / \mathrm{dL}(76 \mathrm{nmol} / \mathrm{L})(\mathrm{S} 82.1 \%$, Sp 88.9\%, AUC 0.952 (95\% CI 0.900-1.000); $P<0.001$ ) (Fig. 4) and for recurrence $>1.33 \mu \mathrm{g} / \mathrm{dL}(36.7 \mathrm{nmol} / \mathrm{L})(\mathrm{S} 65 \%$, Sp 88.95\%, AUC 0.809 (95\% CI 0.691-0.920); $P<0.001$ ), respectively.

Lastly, a time to cortisol nadir above $46.5 \mathrm{~h}$ was indicative of recurrence (S 70\%, Sp 83.3\%, AUC 0.769 (95\% CI 0.642-0.896); $P<0.001$ ).

\section{Discussion}

In our series, $86.2 \%(56 / 65)$ of the cases $(93.02 \%(40 / 43)$ of the microadenomas, $75 \%(12 / 16)$ of the macroadenomas, and $66.7 \%(4 / 6)$ of the cases without MRI data) showed late remission after surgery. The mean remission rate reported in the literature is comparatively lower: $77.8 \%$ (82.2\% microadenomas, $60.1 \%$ macroadenomas) $(1,6)$.

Table 3 Impact of transsphenoidal resection according to adenoma identification by MRI.

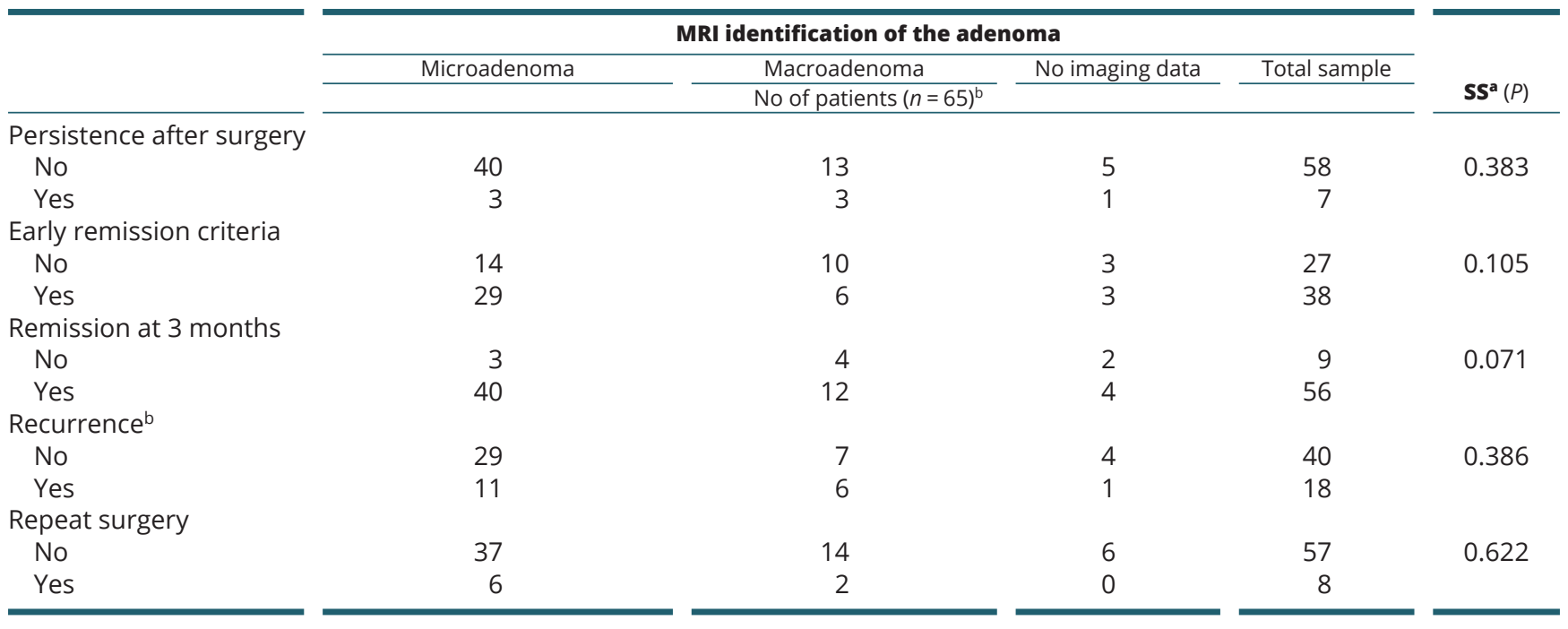

aSS: statistical significance (chi-squared test). ${ }^{\mathrm{b} T h e}$ cases of recurrence are analyzed with respect to the 58 cases in which CD did not persist after surgery.

https://ec.bioscientifica.com

https://doi.org/10.1530/EC-19-0297
(C) 2019 The authors Published by Bioscientifica Ltd

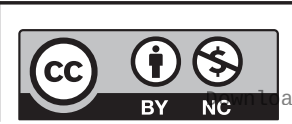

This work is licensed under a Creative Commons Attribution-NonCommercial 4.0 International License. ded from Bioscientifica.com at 04/26/2023 10:31:20AM via free access 


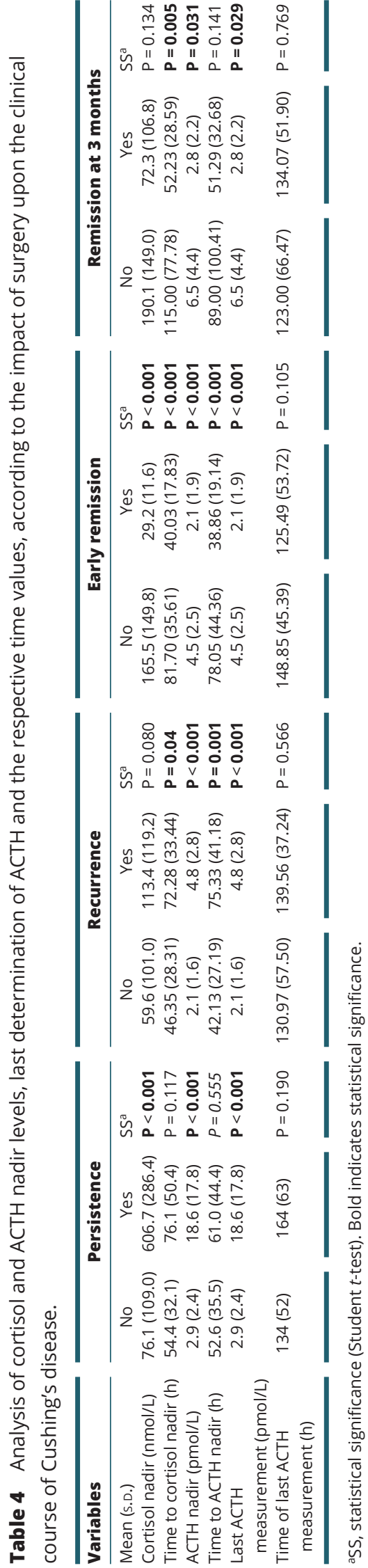

https://ec.bioscientifica.com https://doi.org/10.1530/EC-19-0297 (c) 2019 The authors Published by Bioscientifica Ltd
Our overall recurrence rate was 31\% (18 of the 58 cases that met the late remission criteria), with a mean time to recurrence of 22.8 months (range 1-72). This figure is lower than reported in the literature, with a mean time to recurrence of 67 months $(1,2,3,4,5)$. Of the 18 recurrences, 8 corresponded to patients that had already been reoperated upon due to $\mathrm{CD}$ recurrence after first surgery in our center. Accordingly, on excluding these eight recurrences following repeat surgery, the recurrence rate after first surgery in our center would be $20 \%$ - this figure being slightly higher than the average reported by previous studies (13.2\%) $(1,2,3,4,5,6)$.

In our series, the presurgical plasma ACTH values were not found to be of prognostic utility in reference to $C D$ after surgery, as has already been reported elsewhere (8).

Following transsphenoidal resection, we recorded significantly lower mean ACTH nadir values in patients without disease persistence, in those with early and late remission, and in those without $\mathrm{CD}$ recurrence, thus reinforcing the idea that the ACTH nadir levels may play a prognostic role in the early postoperative period.

The differences in mean time to ACTH nadir after surgery were significant in relation to early remission ( 38.9 vs $78.1 \mathrm{~h}$ ) and recurrence (75.3 vs $42.1 \mathrm{~h}$ ). The time to ACTH nadir is therefore also of prognostic importance.

It must be taken into account that the ACTH nadir is the level coinciding with cortisol nadir $<2 \mu \mathrm{g} / \mathrm{dL}$ $(55.2 \mathrm{nmol} / \mathrm{L})$. The monitoring of ACTH is suspended once this cortisol level has been reached. Therefore, ACTH has not necessarily reached its theoretically lowest level after surgery, particularly in the case of macroadenomas. We thus determined ACTH in the 48 hours before hospital discharge in all patients, performing sampling an average of 137 hours (5.7 days) after the operation. Although there may have been interferences in those patients requiring treatment for secondary adrenal insufficiency, we also analyzed the prognostic usefulness of this last ACTH measurement during admission and found values practically identical to those of the ACTH nadir in the postoperative period. The determination of ACTH at hospital discharge following $\mathrm{CD}$ surgery is therefore a less complex alternative and offers the same prognostic validity as serial ACTH determinations after surgery. Both parameters showed significantly lower mean values in microadenomas versus macroadenomas.

The ANN analysis for the prediction of late remission and recurrence showed a dominant influence of the ACTH values. The ANN for the prediction of recurrence after surgery showed a dominant influence of the time taken to reach the ACTH nadir and ACTH determination 


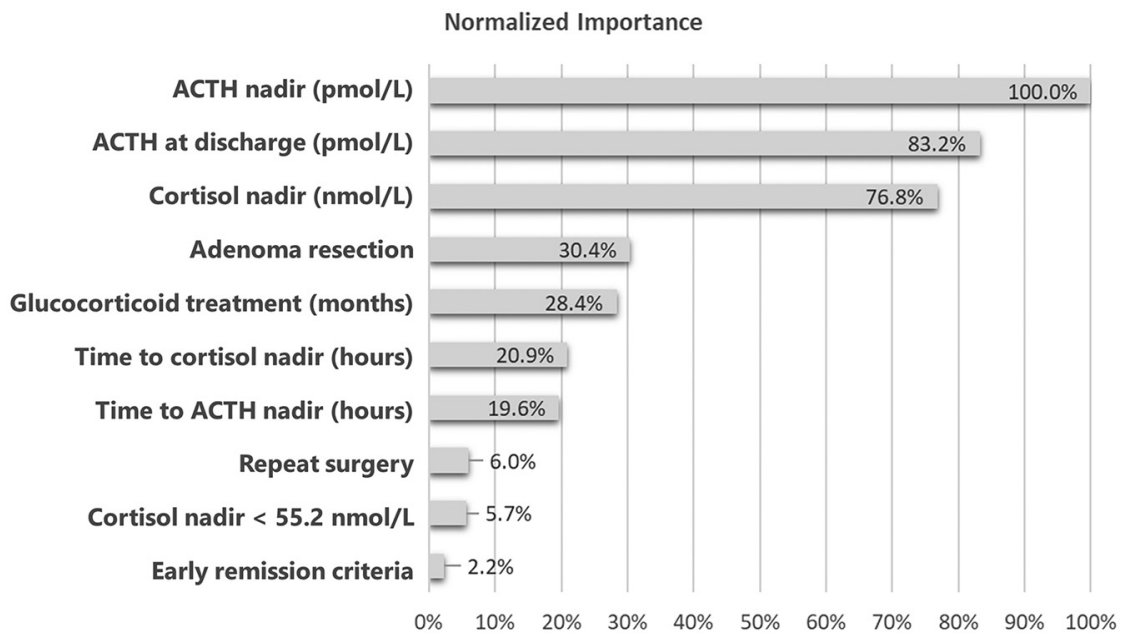

\section{Figure 1}

Artificial neural network (ANN) analysis for predicting remission at 3 months of $C D$. at discharge. This consolidates the results of the bivariate analysis and demonstrates the relevance of last ACTH measurement and the time taken to reach the lowest ACTH value in the immediate postoperative period.

It is important to underscore that ANN is a multivariate statistical analysis that defines which independent variables have more weight in the prediction ( $>50 \%$ normalized importance). To our knowledge, this analysis has not been previously applied to CD predictive factors after surgery and demonstrates that ACTH values are even more important than cortisol values. The cortisol nadir is more important for predicting late remission than cortisol $<2 \mu \mathrm{g} / \mathrm{dL}(52.2 \mathrm{nmol} / \mathrm{L})$, which could indicate that lowest (nadir) values are better than a cut-off point.

In relation to the ACTH nadir and last measurement of ACTH before discharge, the cut-off point with the best sensitivity-specificity combination as established from the ROC curves was $\leq 15 \mathrm{pg} / \mathrm{mL}$ (3.3 pmol/L). This prognostic cut-off point of the ACTH nadir is similar to the values reported in the literature, ranging between 10 and $20 \mathrm{pg} / \mathrm{mL}(2.2-4.4 \mathrm{pmol} / \mathrm{L})$ (35) and is clearly lower than the ACTH $<34 \mathrm{pg} / \mathrm{mL}$ ( $7.5 \mathrm{pmol} / \mathrm{L})$ level described by other authors (15). On the basis of our results, we propose an ACTH nadir and ACTH concentration before discharge of $<15 \mathrm{pg} / \mathrm{mL}(3.3 \mathrm{pmol} / \mathrm{L})$ as an indicator of good shortand long-term prognosis. The literature describes that reaching an undetectable ACTH nadir concentration, together with a cortisol level of $<2 \mu \mathrm{g} / \mathrm{dL}(55.2 \mathrm{nmol} / \mathrm{L})$, is associated to a greater probability of long-term remission (33). On reviewing the ACTH cut-off points after surgery in relation to the prognosis of $\mathrm{CD}$, we found values of under $6.9 \mathrm{pg} / \mathrm{mL} \quad(1.5 \mathrm{pmol} / \mathrm{L})$ and over $36.1 \mathrm{pg} / \mathrm{mL}$ (7.9 pmol/L) to afford a specificity of $100 \%$ in identifying with remission and recurrence respectively, though the

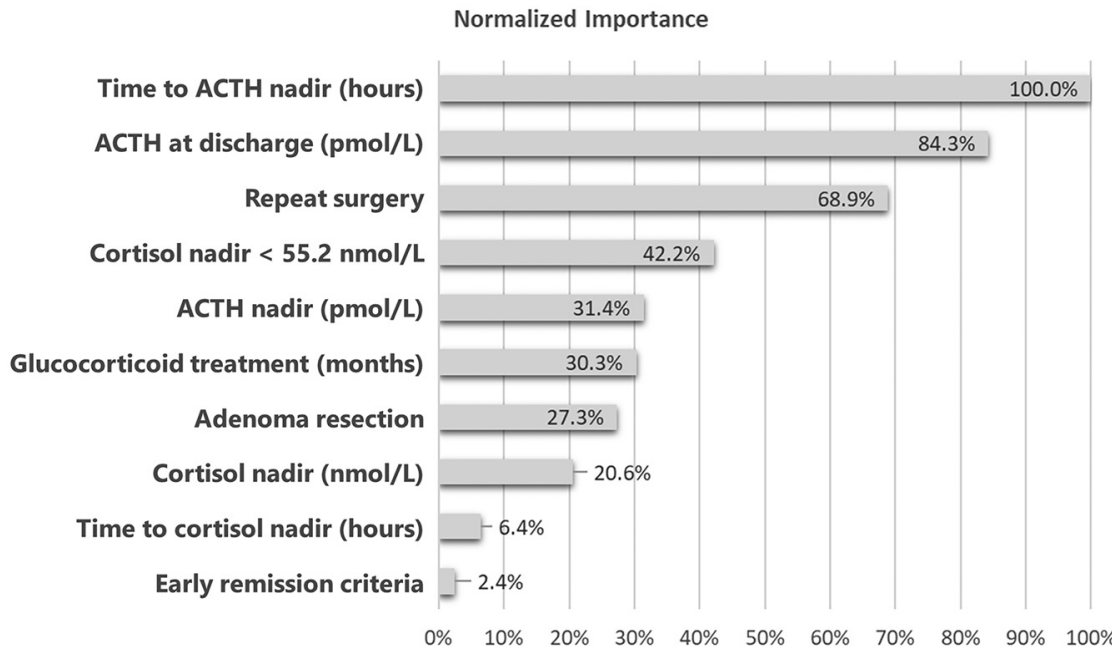

Figure 2

Artificial neural network (ANN) analysis for predicting recurrence of $C D$. https://ec.bioscientifica.com https://doi.org/10.1530/EC-19-0297
(C) 2019 The authors Published by Bioscientifica Ltd
This work is licensed under a Creative Commons Attribution-NonCommercial 4.0 International License. ded from Bioscientifica.com at 04/26/2023 10:31:20AM via free access 
ROC curve last ACTH (pmol/L) for Persistence

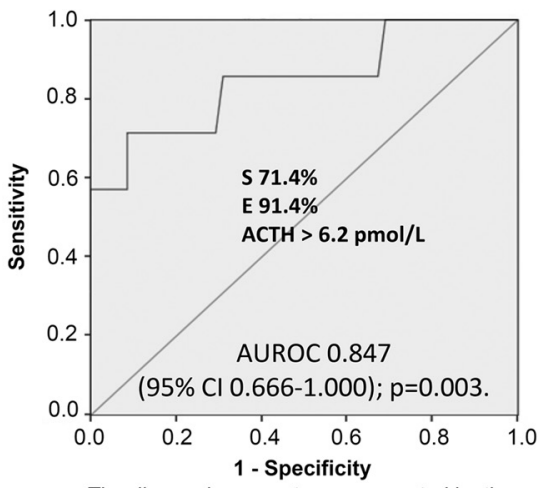

The diagonal segments are generated by ties

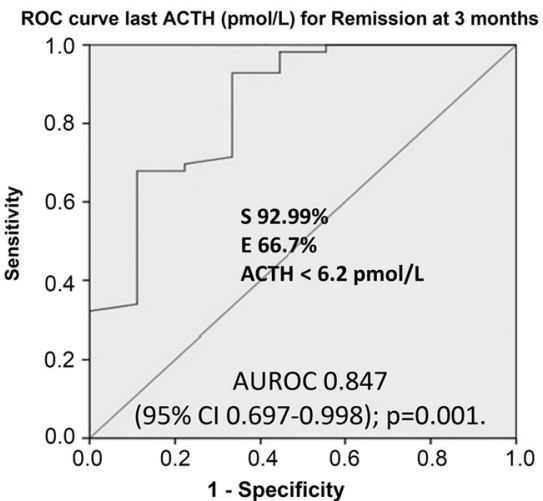

The diagonal segments are generated by ties

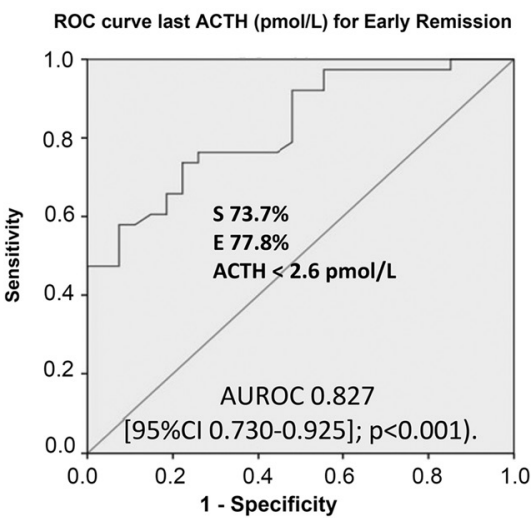

The diagonal segments are generated by ties

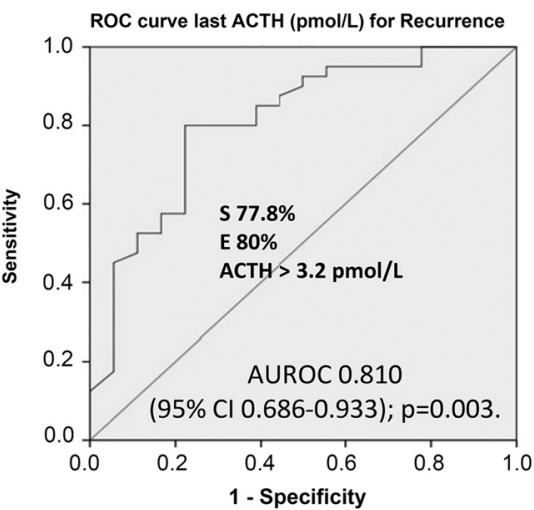

The diagonal segments are generated by ties
Figure 3

Receiver-operating characteristic (ROC) curves corresponding to the determination of ACTH before hospital discharge. AUC, area under the receiver-operating characteristic curves; $\mathrm{Cl}$, confidence interval; S, sensitivity; Sp, specificity.

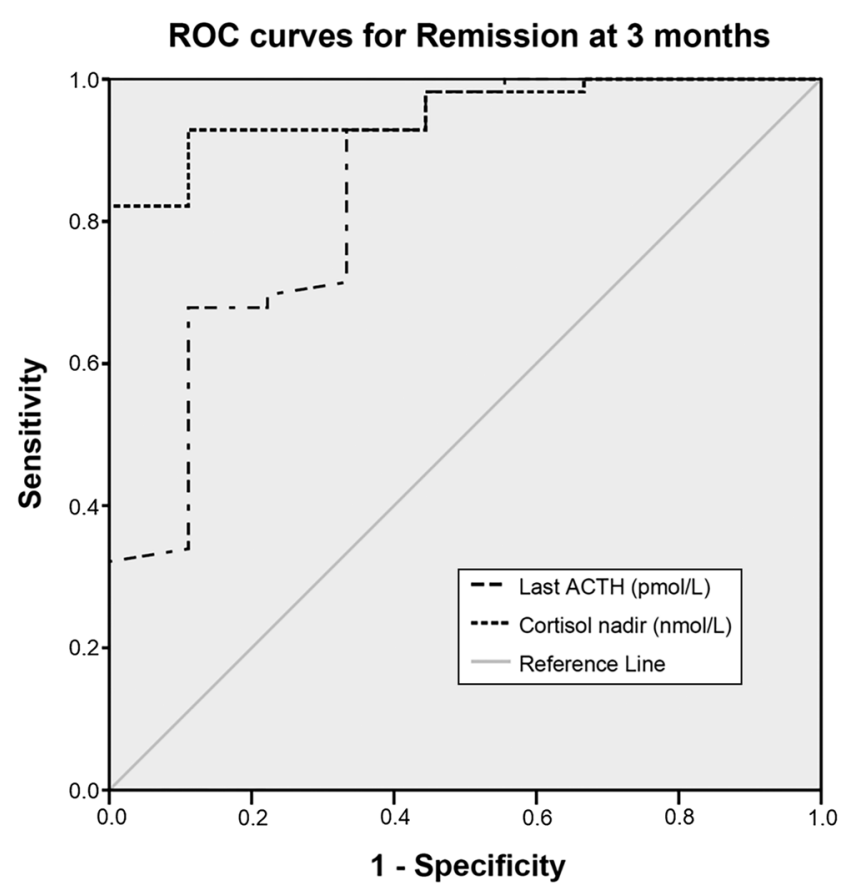

The diagonal segments are generated by ties.

Figure 4

Receiver-operating characteristic (ROC) curves corresponding to the determination of ACTH before hospital discharge and cortisol nadir value. sensitivity is low. The differences between microadenomas and macroadenomas must be taken into account, since the latter are associated to higher postoperative cortisol and ACTH levels, and may take longer after surgery in reaching nadir concentrations. Indeed, the nadir may even be reached after patient discharge from hospital.

The timing of hypocortisolemia has been found to be critical in detecting late recurrences $(8,24,26)$. However, the prognostic role of the time in reaching the ACTH nadir has been little described to date in the immediate postoperative period of $\mathrm{CD}$. The dynamics of changes in plasma ACTH values after adenoma resection could also be of prognostic value, though the available data are limited and contradictory. An ACTH reduction of $>40 \%$ after the first hour postsurgery (32) or an early and rapid decrease in ACTH values $(15,25,33,36,37,38)$ could discriminate those patients who will achieve late remission.

However, in other studies, plasma ACTH changes after surgery did not predict remission (34).

\section{Strengths and limitations}

This prospective study is the first to describe the prognostic usefulness of plasma ACTH measurement before hospital

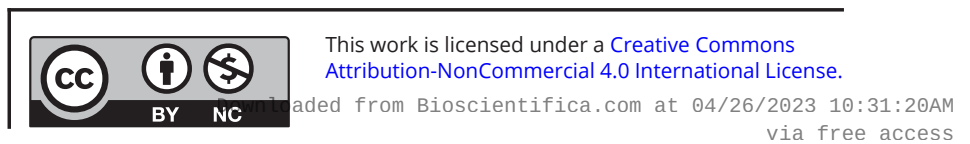


discharge following transsphenoidal surgery - the prognostic utility being similar to that of the plasma ACTH nadir determined after the operation. ACTH measurement before discharge is less complex compared to serial determinations of ACTH. It can be performed routinely along with hormonal evaluation at discharge, without an apparent influence of replacement treatment. While the surgical technique and surgeon expertise can affect outcomes, all included patients underwent surgery at a single reference center. The short half-life of ACTH compared to cortisol, and the lack of effect of possible adrenal nodular hyperplasia on the delayed decline of cortisol should favor the usefulness of ACTH. However, it is complicated to generalize the use of postoperative ACTH. Each center should establish its own cut-off values, depending on the test used to measure ACTH, and taking into account the difficulties of standardizing extraction and analysis.

Although a mean follow-up time of 64.18 (32.53) months may seem sufficient, a longer duration of follow-up is required, since CD recurrence may occur as long as 10 years after surgery (2). Other limitations are the arbitrary definition of early remission based on a cortisol nadir of $2 \mu \mathrm{g} / \mathrm{dL}(55.2 \mathrm{nmol} / \mathrm{L})$ and the possible influence of corticosteroid replacement therapy upon the ACTH levels (hydrocortisone was always used in our series, as it is more physiological and has a shorter half-life).

A more in-depth investigation into ACTH dynamics is needed in the immediate postoperative period in order to validate our results.

\section{Conclusions}

In the immediate postoperative period of patients with $\mathrm{CD}$, the ACTH concentration is of prognostic utility in relation to late disease remission. We propose an ACTH nadir of $<15 \mathrm{pg} / \mathrm{mL}(3.3 \mathrm{pmol} / \mathrm{L})$ as a good long-term prognostic indicator in $\mathrm{CD}$ following transsphenoidal surgery, referred to the prevention of recurrence. This same cut-off point is also applicable to the determination of ACTH before hospital discharge - the present study being the first to describe its relevance in predicting late disease remission and the absence of recurrence after transsphenoidal removal of the adenoma. Furthermore, reaching the ACTH nadir in less time is associated to a lesser recurrence rate.

\section{Declaration of interest}

The authors declare that there is no conflict of interest that could be perceived as prejudicing the impartiality of the research reported.

\section{Funding}

This work did not receive any specific grant from any funding agency in the public, commercial or not-for-profit sector.

\section{Acknowledgments}

Thanks are due to the Intensive Care Unit, Laboratory and Pathology and Radiology Departments of Hospital Universitario de la Ribera. Thanks are also due to all the endocrinologists who referred patients to our center from the following hospitals: Hospital Doctor Peset (Valencia), Hospital Arnau de Vilanova (Valencia), Hospital Clínico Universitario (Valencia), Hospital San Francisco de Borja (Gandía), Hospital de Sagunto (Sagunto), Hospital de Manises (Manises), Hospital Lluís Alcanyís (Xàtiva), Hospital General de Requena (Requena), Hospital General Universitari de Castelló (Castellón); Hospital Universitario de la Plana (Villareal), Hospital de La Vega Baja (Orihuela), Hospital General de Elda (Elda), Hospital General Universitario Virgen de la Arrixaca (Murcia), Hospital General Universitario Morales Meseguer (Murcia), Hospital General Universitario Reina Sofía (Murcia), and Hospital General Universitario Santa María del Rosell (Cartagena).

\section{References}

1 Petersenn S, Beckers A, Ferone D, van der Lely A, Bollerslev J, Boscaro M, Brue T, Bruzzi P, Casanueva FF, Chanson P, et al. THERAPY OF ENDOCRINE DISEASE: Outcomes in patients with Cushing's disease undergoing transsphenoidal surgery: systematic review assessing criteria used to define remission and recurrence. European Journal of Endocrinology 2015172 R227-R239. (https://doi. org/10.1530/EJE-14-0883)

2 Biller BMK, Grossman AB, Stewart PM, Melmed S, Bertagna X, Bertherat J, Buchfelder M, Colao A, Hermus AR, Hofland LJ, et al. Treatment of adrenocorticotropin-dependent Cushing's syndrome: a consensus statement. Journal of Clinical Endocrinology and Metabolism 200893 2454-2462. (https://doi.org/10.1210/jc.2007-2734)

3 Newell-Price J, Bertagna X, Grossman AB \& Nieman LK. Cushing's syndrome. Lancet 2006367 1605-1617. (https://doi.org/10.1016/ S0140-6736(06)68699-6)

4 Fleseriu M, Hamrahian AH, Hoffman AR, Kelly DF, Katznelson L \& AACE Neuroendocrine and Pituitary Scientific Committee. American Association of Clinical Endocrinologists and American College of endocrinology. Disease state clinical review: diagnosis of recurrence in Cushing disease. Endocrine Practice 201622 1436-1448. (https:// doi.org/10.4158/EP161512.DSCR)

5 Abu Dabrh AM, Singh Ospina NM, Al Nofal A, Farah WH, Barrionuevo P, Sarigianni M, Mohabbat AB, Benkhadra K, Carranza Leon BG, Gionfriddo MR, et al. Predictors of biochemical remission and recurrence after surgical and radiation treatments of Cushing disease: a systematic review and meta-analysis. Endocrine Practice 201622 466-475. (https://doi.org/10.4158/EP15922.RA)

6 Pivonello R, De Leo M, Cozzolino A \& Colao A. The treatment of Cushing's disease. Endocrine Reviews 201536 385-486. (https://doi. org/10.1210/er.2013-1048)

7 Lacroix A, Feelders RA, Stratakis CA \& Nieman LK. Cushing's syndrome. Lancet 2015386 913-927. (https://doi.org/10.1016/ S0140-6736(14)61375-1)

8 Abellán Galiana P, Fajardo Montañana C, Riesgo Suárez PA, Gómez Vela J, Escrivá CM \& Lillo VR. Factores pronósticos de remisión a largo plazo tras cirugía transesfenoidal en la enfermedad de Cushing. Endocrinología y Nutrición 201360 475-482. (https://doi. org/10.1016/j.endonu.2012.09.009)

9 Ramm-Pettersen J, Halvorsen H, Evang JA, Rønning P, Hol PK, Bollerslev J, Berg-Johnsen J \& Helseth E. Low immediate postoperative serum-cortisol nadir predicts the short-term, but not 
long-term, remission after pituitary surgery for Cushing's disease. BMC Endocrine Disorders 201515 62. (https://doi.org/10.1186/ s12902-015-0055-9)

10 Simmons NE, Alden TD, Thorner MO \& Laws ER. Serum cortisol response to transsphenoidal surgery for Cushing disease. Journal of Neurologicalsurgery 200195 1-8. (https://doi.org/10.3171/ jns.2001.95.1.0001)

11 Esposito F, Dusick JR, Cohan P, Moftakhar P, McArthur D, Wang C, Swerdloff RS \& Kelly DF. CLINICAL REVIEW: Early morning cortisol levels as a predictor of remission after transsphenoidal surgery for Cushing's disease. Journal of Clinical Endocrinology and Metabolism 200691 7-13. (https://doi.org/10.1210/jc.2005-1204)

12 Rollin GAFS, Ferreira NP, Junges M, Gross JL \& Czepielewski MA. Dynamics of serum cortisol levels after transsphenoidal surgery in a cohort of patients with Cushing's disease. Journal of Clinical Endocrinology and Metabolism 200489 1131-1139. (https://doi. org/10.1210/jc.2003-031170)

13 AbdelMannan D, Selman WR \& Arafah BM. Peri-operative management of Cushing's disease. Reviews in Endocrine and Metabolic Disorders 201011 127-134. (https://doi.org/10.1007/s11154-0109140-6)

14 Nieman LK, Biller BMK, Findling JW, Murad MH, Newell-Price J, Savage MO, Tabarin A \& Endocrine Society. Treatment of Cushing's syndrome: an Endocrine Society clinical practice guideline. Journal of Clinical Endocrinology and Metabolism 2015100 2807-2831. (https:// doi.org/10.1210/jc.2015-1818)

15 Chee GH, Mathias DB, James RA \& Kendall-Taylor P. Transsphenoidal pituitary surgery in Cushing's disease: can we predict outcome? Clinical Endocrinology 200154 617-626. (https://doi.org/10.1046/ j.1365-2265.2001.01261.x)

16 Yap LB, Turner HE, Adams CBT \& Wass JAH. Undetectable postoperative cortisol does not always predict long-term remission in Cushing's disease: a single centre audit. Clinical Endocrinology 2002 56 25-31. (https://doi.org/10.1046/j.0300-0664.2001.01444.x)

17 Acebes JJ, Martino J, Masuet C, Montanya E \& Soler J. Early postoperative ACTH and cortisol as predictors of remission in Cushing's disease. Acta Neurochirurgica 2007149 471-477; discussion 477-479. (https://doi.org/10.1007/s00701-007-1133-1)

18 Hammer GD, Tyrrell JB, Lamborn KR, Applebury CB, Hannegan ET, Bell S, Rahl R, Lu A \& Wilson CB. Transsphenoidal microsurgery for Cushing's disease: initial outcome and long-term results. Journal of Clinical Endocrinology and Metabolism 200489 6348-6357. (https:// doi.org/10.1210/jc.2003-032180)

19 Rollin G, Ferreira NP \& Czepielewski MA. Prospective evaluation of transsphenoidal pituitary surgery in 108 patients with Cushing's disease. Arquivos Brasileiros de Endocrinologia e Metabologia 200751 1355-1361. (https://doi.org/10.1590/S0004-27302007000800022)

20 Trainer PJ, Lawrie HS, Verhelst J, Howlett TA, Lowe DG, Grossman AB, Savage MO, Afshar F \& Besser GM. Transsphenoidal resection in Cushing's disease: undetectable serum cortisol as the definition of successful treatment. Clinical Endocrinology $1993 \mathbf{3 8}$ 73-78. (https://doi.org/10.1111/j.1365-2265.1993.tb00975.x)

21 Estrada J, García-Uría J, Lamas C, Alfaro J, Lucas T, Diez S, Salto L \& Barceló B. The complete normalization of the adrenocortical function as the criterion of cure after transsphenoidal surgery for Cushing's disease. Journal of Clinical Endocrinology and Metabolism 200186 5695-5699. (https://doi.org/10.1210/jcem.86.12.8069)

22 Invitti C, Pecori Giraldi F, de Martin M \& Cavagnini F. Diagnosis and management of Cushing's syndrome: results of an Italian multicentre study. Study group of the Italian Society of Endocrinology on the Pathophysiology of the hypothalamic-pituitary-adrenal axis. Journal of Clinical Endocrinology and Metabolism 199984 440-448. (https:// doi.org/10.1210/jcem.84.2.5465)

23 Atkinson AB, Kennedy A, Wiggam MI, McCance DR \& Sheridan B. Long-term remission rates after pituitary surgery for
Cushing's disease: the need for long-term surveillance. Clinical Endocrinology 200563 549-559. (https://doi.org/10.1111/j.13652265.2005.02380.x)

24 Krikorian A, Abdelmannan D, Selman WR \& Arafah BM. Cushing disease: use of perioperative serum cortisol measurements in early determination of success following pituitary surgery. Neurosurgical Focus 200723 E6. (https://doi.org/10.3171/foc.2007.23.3.8)

25 Flitsch J, Knappe UJ \& Lüdecke DK. The use of postoperative ACTH levels as a marker for successful transsphenoidal microsurgery in Cushing's disease. Zentralblatt Für Neurochirurgie 200364 6-11. (https://doi.org/10.1055/s-2003-37145)

26 Ironside N, Chatain G, Asuzu D, Benzo S, Lodish M, Sharma S, Nieman L, Stratakis CA, Lonser RR \& Chittiboina P. Earlier postoperative hypocortisolemia may predict durable remission from Cushing's disease. European Journal of Endocrinology 2018178 255-263. (https://doi.org/10.1530/EJE-17-0873)

27 Lindsay JR, Oldfield EH, Stratakis CA \& Nieman LK. The postoperative basal cortisol and CRH tests for prediction of long-term remission from Cushing's disease after transsphenoidal surgery. Journal of Clinical Endocrinology and Metabolism 201196 2057-2064. (https://doi.org/10.1210/jc.2011-0456)

28 Alwani RA, de Herder WW, van Aken MO, van den Berge JH, Delwel EJ, Dallenga AHG, De Jong FH, Lamberts SWJ, van der Lely AJ \& Feelders RA. Biochemical predictors of outcome of pituitary surgery for Cushing's disease. Neuroendocrinology 201091 169-178. (https://doi.org/10.1159/000258677)

29 Valéro R, Vallette-Kasic S, Conte-Devolx B, Jaquet P \& Brue T. The desmopressin test as a predictive factor of outcome after pituitary surgery for Cushing's disease. European Journal of Endocrinology 2004 151 727-733. (https://doi.org/10.1530/eje.0.1510727)

30 Barbot M, Albiger N, Koutroumpi S, Ceccato F, Frigo AC, Manara R, Fassina A, Gardiman MP, Scanarini M, Mantero F, et al. Predicting late recurrence in surgically treated patients with Cushing's disease. Clinical Endocrinology 201379 394-401. (https://doi.org/10.1111/ cen.12133)

31 Losa M, Bianchi R, Barzaghi R, Giovanelli M \& Mortini P. Persistent adrenocorticotropin response to desmopressin in the early postoperative period predicts recurrence of Cushing's disease. Journal of Clinical Endocrinology and Metabolism 200994 3322-3328. (https:// doi.org/10.1210/jc.2009-0844)

32 Graham KE, Samuels MH, Raff H, Barnwell SL \& Cook DM. Intraoperative adrenocorticotropin levels during transsphenoidal surgery for Cushing's disease do not predict cure. Journal of Clinical Endocrinology and Metabolism 199782 1776-1779. (https://doi. org/10.1210/jcem.82.6.4005)

33 Salmon PM, Loftus PD, Dodd RL, Harsh G, Chu OS \& Katznelson L. Utility of adrenocorticotropic hormone in assessing the response to transsphenoidal surgery for Cushing's disease. Endocrine Practice 2014 20 1159-1164. (https://doi.org/10.4158/EP14140.OR)

34 Pimentel-Filho FR, Cukiert A, Miyashita F, Huayllas MKP Knoepfelmacher M, Salgado LR \& Liberman B. Adrenocorticotropin levels do not change during early recovery of transsphenoidal surgery for ACTH-secreting pituitary tumors. Journal of Endocrinological Investigation 200124 83-87. (https://doi.org/10.1007/ BF03343818)

35 Czirják S, Bezzegh A, Gál A \& Rácz K. Intra- and postoperative plasma ACTH concentrations in patients with Cushing's disease cured by transsphenoidal pituitary surgery. Acta Neurochirurgica $2002 \mathbf{1 4 4}$ 971-977. (https://doi.org/10.1007/s00701-002-0984-8)

36 Hameed N, Yedinak CG, Brzana J, Gultekin SH, Coppa ND, Dogan A, Delashaw JB \& Fleseriu M. Remission rate after transsphenoidal surgery in patients with pathologically confirmed Cushing's disease, the role of cortisol, ACTH assessment and immediate reoperation: a large single center experience. Pituitary 201316 452-458. (https:// doi.org/10.1007/s11102-012-0455-z) https://ec.bioscientifica.com https://doi.org/10.1530/EC-19-0297 (c) 2019 The authors Published by Bioscientifica Ltd

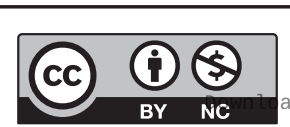

This work is licensed under a Creative Commons Attribution-NonCommercial 4.0 International License. ded from Bioscientifica.com at 04/26/2023 10:31:20AM 
37 Fahlbusch R, Buchfelder M \& Müller OA. Transsphenoidal surgery for Cushing's disease. Journal of the Royal Society of Medicine 198679 262-269. (https://doi.org/10.1177/014107688607900504)

38 Srinivasan L, Laws ER, Dodd RL, Monita MM, Tannenbaum CE, Kirkeby KM, Chu OS, Harsh IV GR \& Katznelson L. The dynamics of post-operative plasma ACTH values following transsphenoidal surgery for Cushing's disease. Pituitary 201114 312-317. (https://doi. org/10.1007/s11102-011-0295-2)

39 Barbetta L, Dall'Asta C, Tomei G, Locatelli M, Giovanelli M \& Ambrosi B. Assessment of cure and recurrence after pituitary surgery for Cushing's disease. Acta Neurochirurgica 2001143 477-481; discussion 481-482. (https://doi.org/10.1007/s007010170077)

40 El Asmar N, Rajpal A, Selman WR \& Arafah BM. The value of perioperative levels of ACTH, DHEA, and DHEA-S and tumor size in predicting recurrence of Cushing disease. Journal of Clinical Endocrinology and Metabolism 2018103 477-485. (https://doi. org/10.1210/jc.2017-01797)

41 Asuzu D, Chatain GP, Hayes C, Benzo S, McGlotten R, Keil M, Beri A, Sharma ST, Nieman L, Lodish M, et al. Normalized early postoperative cortisol and ACTH values predict nonremission after surgery for Cushing disease. Journal of Clinical Endocrinology and Metabolism 2017 102 2179-2187. (https://doi.org/10.1210/jc.2016-3908)

42 Harker P, Feo-Lee O, Giraldo-Grueso M \& Puentes JC. Effectiveness of bilateral inferior petrosal sinuses sampling in tumor lateralization: intraoperative findings and postoperative results. Journal of Neurological Surgery: Part B, Skull Base 201778 506-511. (https://doi. org/10.1055/s-0037-1604409)

43 Hawley JM, Owen LJ, Lockhart SJ, Monaghan PJ, Armston A, Chadwick CA, Wilshaw H, Freire M, Perry L \& Keevil BG. Serum cortisol: an up-to-date assessment of routine assay performance. Clinical Chemistry 201662 1220-1229. (https://doi.org/10.1373/ clinchem.2016.255034)

44 Verschraegen I, Anckaert E, Schiettecatte J, Mees M, Garrido A, Hermsen D, Lentjes EG, Liebert A, Roth HJ, Stamminger G, et al. Multicenter evaluation of a rapid electrochemiluminescent adrenocorticotropic hormone (ACTH) immunoassay. Clinica Chimica Acta: International Journal of Clinical Chemistry 2007380 75-80. (https://doi.org/10.1016/j.cca.2006.12.031)

Received in final form 18 July 2019

Accepted 5 August 2019

Accepted Preprint published online 6 August 2019
This work is licensed under a Creative Commons Attribution-NonCommercial 4.0 International License. ded from Bioscientifica.com at 04/26/2023 10:31:20AM 